\title{
HISTORY OF MEDICINE, SURGERY AND UROLOGY IN BRESLAU/WROCLAW
}

\section{HISTORIA MEDYCYNY, CHIRURGII I UROLOGII WE WROCLAWIU (BRESLAU)}

Klaus-Groth-Str. 16

D-45472 Muelheim an der Ruhr, Germany

\begin{abstract}
Streszczenie
Opisano rozwój medycyny we Wrocławiu od XIV w. oraz przedstawiono sylwetki lekarzy działających w tym mieście, przede wszystkim Ślązaków. Celem pracy było również opisanie rozwoju szpitalnictwa, szkolenia medycyny i powstania urologii we Wrocławiu oraz ukazanie życiorysów znanych chirurgów zajmujących się zwłaszcza leczeniem chorób układu moczowo-płciowego. Opisano także początki szkolenia medyczno-chirurgicznego we Wrocławiu oraz powstanie samodzielnej akademickiej urologii w tym mieście. Przedstawiono pierwszego urologa wrocławskiego prof. Floriana Nowackiego oraz ukazano jego rolę w powstaniu samodzielnego Oddziału i Kliniki Urologicznej po II wojnie światowej.

W pracy wykorzystano materiały i dokumentację z bibliotek i archiwów zarówno polskich, jak i niemieckich.
\end{abstract}

Ha s $\nmid$ a: historia medycyny - historia urologii - Wrocław.

\section{Summary}

The development of medicine in Breslau from the $14^{\text {th }}$ century has been described and its famous physicians, above all Silesians, are introduced. The aim of the study is to present the development history of hospital services and the teaching of medicine, and also the development of urology in Breslau. Well known Breslau surgeons who were interested in surgery of the genitourinary system are also presented. The aim of the study is to present a brief history of Breslau medicine and surgery from its beginning to the end of World War II. The development of urology and its separation from surgery after World War II is also briefly described. Professor Florian Nowacki, Breslaus's first urologist, is also introduced.

Extensive research was undertaken for the collection of literature and documents in German and Polish archives and libraries to prepare this study

K e y w o r d s: history of medicine - history of urology Breslau.

\section{Introduction}

Breslau (Wrocław) was, and still is, the main city of Silesia, the history of which is intertwined with the history of Poland, Bohemia, Austria and Germany. From the $10^{\text {th }}$ to the $14^{\text {th }}$ century it was ruled by princes of the Polish Piast dynasty, from the $14^{\text {th }}$ to the $16^{\text {th }}$ century it belonged to the Czech Kingdom, from 1526-1741 the Habsburgs controlled it, and from 1741 to 1918 it was ruled by the Hohenzollerns, Prussian kings and German emperors.

From 1918 to 1939 Lower Silesia was a province of the Weimar Republic and then Nazi Germany. From 1939, after the invasion of Poland, the whole of Silesia was incorporated into the German Third Reich. Since the end of the World War II it has belonged to Poland. On $9^{\text {th }}$ May 1945 the Soviet military authorities handed the City of Wrocław over to the Polish administration.

Wrocław is a city of many names: Wrotizla, Wretslaw, Presslau, and Breslau. All of these apparently different names 


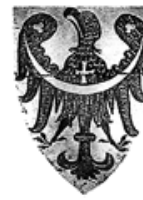

Silesian's

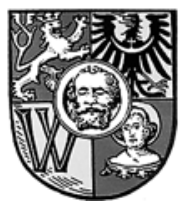

1530-1938

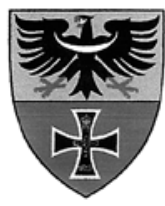

1938-1945

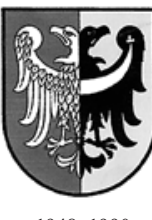

1948-1990

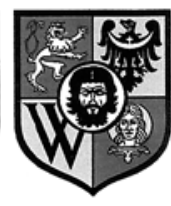

from 1990
Fig. 1. Silesian and Breslau's Coat of arms

represent the same place on the map of Europe. All these names denote one city, which in its history has belonged to four different nations (Fig. 1). Over the course of its history most of Wrocław's citizens have been Poles, Czechs, Germans and Jews, who imbued the life of the city with their own native cultures, traditions, religions and science. Ten Nobel Prize laureates have come from this city.

Before the end of 1945 there were no independent urology wards in Breslau, and urological surgery was in the hands of surgeons and, in the centuries before that, in the hands of academically uneducated persons such as bath house attendants, barbers, and wandering surgeons. From the $19^{\text {th }}$ century until the 1950 s all of the city's surgical departments performed operations on the genitourinary organs to a greater or lesser extent. The only director of a surgical clinic at the university to engage in anything other than routine surgery in the genitourinary field was Prof. Johann von Mikulicz-Radecki (1850-1905).

The end of the World War II created a new political situation in Europe, and Breslau and Silesia became part of Poland. After the war, the celebrated Polish urologist Prof. Florian Nowacki became the first head of the urology department at All Saints Hospital in Wrocław (formerly: Breslau) in 1946. Between 1953 and 1957 he served as Director of the Urological Clinic at the newly-constituted Academy of Medicine in Wrocław (AMW) [1, 2, 3, 4].

\section{Medicine in Breslau (Wroclaw) up to the $14^{\text {th }}$ century and its famous physicians}

There were not many physicians at the courts of the Polish kings and princes during the rule of the Piast dynasty. Furthermore, Poland did not possess a single medical school until 1364, and only a few Poles travelled to other countries in search of medical knowledge. After Cracow, Breslau was the second centre of Polish medicine up to the $15^{\text {th }}$ century, and the most well-known physicians were Silesians.

In the $14^{\text {th }}$ century, Thomas of Breslau (1297-1378) was a doctor of the Silesian princes. He received his education in Italy and France. For many years he was the physician and astrologer of Henry IV, Silesian princes and the German Emperor Charles IV (1316-1378). He practised in several European countries, until he eventually settled in Breslau, where he entered a monastery independently of his medical practice and, with time, became a suffragan bishop. He was the titular bishop of Sarepta. His main legacy was the Mihi competet, a type of medical dictionary. The work is called the "Silesian canon of Avicenna" due to its lasting medical value. With its progressiveness, this work retained its popularity in Silesia, Bohemia and Germany for nearly 200 years. Other works of his that achieved fame were the medical dictionary Alphabetum, and medical treatise, and Nollie Errara, which are compendiums of medical science and astrology.

The physician to achieve the greatest fame in medicine, however, was Dr. Jan of Grodków (Grottkau, *?-1382). His first medical practice was in Breslau. Later he became physician to the Danish King Waldemar IV Atterdag (1320-1375), and after him, to Casimir the Great (1310-1370, reigned 1333-1370), King of Poland. He is the author of the work How to Stay Healthy.

Another physician of note from those times is Dr. Jan Radlica (Johannes Parvus, *?-1392) of Grodków (Grottkau). He gained his education in Italy, and treated French and Hungarian kings with considerable success for many years. On returning to his native land he became personal physician to Queen Jadwiga (1374-1399), and also to King Władysław Jagiełło (1345-1434), Polish monarchs.

European fame came at this time to Jan Stanko (Johannes Stanconis, 1430-1494) of Breslau. Having completed his studies in Italy, J. Stanko became capitulars physician (he was Canon of Breslau, and subsequently of Cracow) and court physician to Casimir Jagiellończyk (Jagellonian, 1427-1492). From 1470 he was Professor of Medicine at the Academy of Cracow. He operated on Jan Długosz (1415-1480) for cystolithiasis and eye disease. This (in the second half of the $15^{\text {th }}$ century) is the earliest known operation performed in Poland to remove a stone from the bladder. It took place in Cracow, on the person of the Polish chronicler and historian Jan Długosz.

The fact that a Doctor of Medicine performed the operation constitutes an exception, as otherwise we know little of the education, or even quite often of the origin of people carrying out lithotomy operations in Poland. Alongside many

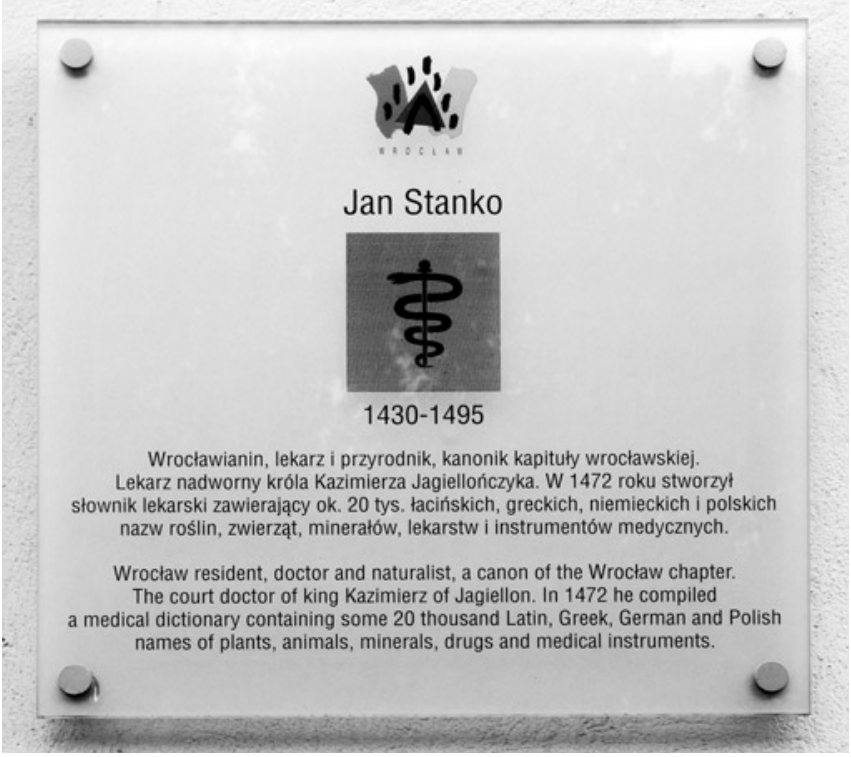

Fig. 2. Memorial plaques of Prof. Jan Stanko 
other publications, J. Stanko left behind what is known as the Antibolomenum or Antidotarium, a dictionary of natural medicine. As the author of the best and most complete large catalogue of flora and fauna in mediaeval Europe, J. Stanko made an enormous contribution to the field of natural sciences. This work is one of the oldest Polish language texts of significance, given that the author was the first to provide Polish names alongside their Latin, Greek and German equivalents.

It is a pity that Antidotarium was never published. This immense work as a manuscript (Cracow, chapter - capitulary archives of Wawel) would not influence the development of the natural sciences and only had a minor impact on scientists. The city of Wrocław has honoured Prof. J. Stanko with a memorial plaque (Fig. 2).

Another physician who was active in Breslau was Jan of Głogów (German: Johann von Schelling von Glogau, about 1445-1507). He was a notable polymath at the turn of the Renaissance, who later became a Professor at the Academy in Cracow, and was the author of a work on the plague (Fig. 3). His greatest passions were grammar, Aristotelian logic, physics, physiology and astronomy. He is thought to have been one of the teachers of Nicolaus Copernicus, who enrolled at the University of Cracow in 1491.

It is also interesting to recall that Nicolas Copernicus (Mikołaj Kopernik, 1473-1543), the famous astronomer, mathematician, economist, physician and originator of the heliocentric theory, began his professional career in Breslau. On 10 ${ }^{\text {th }}$ January 1503 he took on, in addition to his functions as a sexton, those of schoolman at the Holy Cross Church in Breslau. He delegated this function to two monks of the church as his deputies. He remained in this post until 1538. During the years 1491 to 1495 Copernicus studied at the Academy of Cracow. He furthered his studies in Italy, becoming a Doctor of Canon Law in Ferrara on $31^{\text {st }}$ May 1503. He completed his medical studies in Padua and acquired the right to engage in medical practice. He would do this until his death $[5,6,7,8,9]$.

\section{The first physicians in Breslau. Barber - and wandering-surgeons and lithotomists}

In Europe, alongside surgeons who settled in one place, a type of wandering barber-surgeon began to spring up. These would move from place to place in search of patients. For the most part these were people who specialised in just one type of operation, e.g. operations on cataracts or hernias, pulling teeth or removing calculi of the bladder.

The problem of treating bladder calculi arose out of the much greater incidence of this disease in days gone by, compared to today. It is not entirely clear why this was so. Most likely this phenomenon can be explained in terms of the consumption of mainly vegetable products and the drinking of hard water, as well as the lower levels of physical activity among the populace.

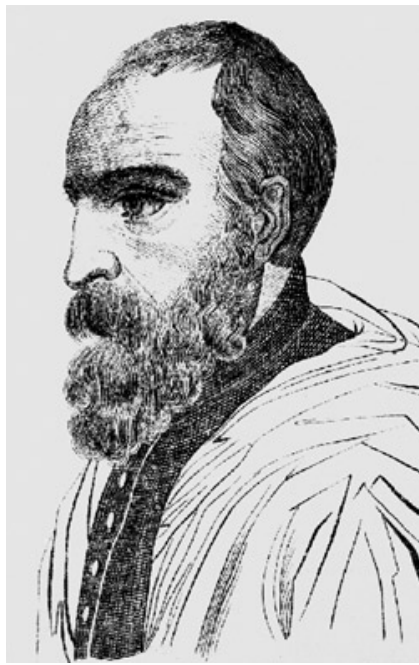

Fig. 3. Johannes von Schelling von Glogau (about 1445-1507)

In the $18^{\text {th }}$ century Breslau had a population of around 50,000 . The city had no more than 7-10 surgeons, so the more accessible services of barber-surgeons and itinerant physicians were in demand.

Itinerant physicians often visited Breslau. These included two famous figures who were the most well-known German itinerant operating physicians. The first of these was Georg Bartisch (1535-1607), surgeon, lithotomist and ophthalmologist, from Saxony (Fig. 4). He was a pioneer of eye operations. In 1583 he performed the first removal of an eyeball on a patient who was suffering from cancer.

His descriptions of the operation to remove a stone from the bladder remained unknown for a long time. It was not until 1893 that Breslau ophthalmologist Prof. Hermann Cohn (1838-1906) accidentally came across a manuscript by $\mathrm{G}$. Bartisch and handed it on to the Berlin urologist Otto Mankiewicz (1871-1918), who published it as the "Dresden manuscript" in 1905. This is the oldest documented source for the transperineal removal of a stone from the bladder in Germany; in effect being the first German lithotomy manual (Fig. 5). The description tells us of the considerable experience of its author, acquired over 28 years of practice as a professional. Georg Bartisch operated successfully on some 450 patients suffering from cystolithiasis. Georg Bartisch also visited Breslau on many occasions to perform operations on patients.

Over two centuries later his fellow-countryman Dr. Johann Andreas Eisenbarth (1663-1727), the second well-known itinerant German surgeon, was in Poland and Breslau on numerous occasions from 1693, and operated on patients (Fig. 6).

During 1697-1698 he visited many towns in Pomerania and Silesia. From Frederick III, Elector of Brandenburg, he obtained a charter to treat patients in Prussia. In Breslau he was given the title Physician for Lower and Upper Silesia. When Augustus the Strong (1670-1733), Elector of Saxony, became King of Poland on $15^{\text {th }}$ August 1697, J.A. Eisenbarth, who already held the privilege, from the 


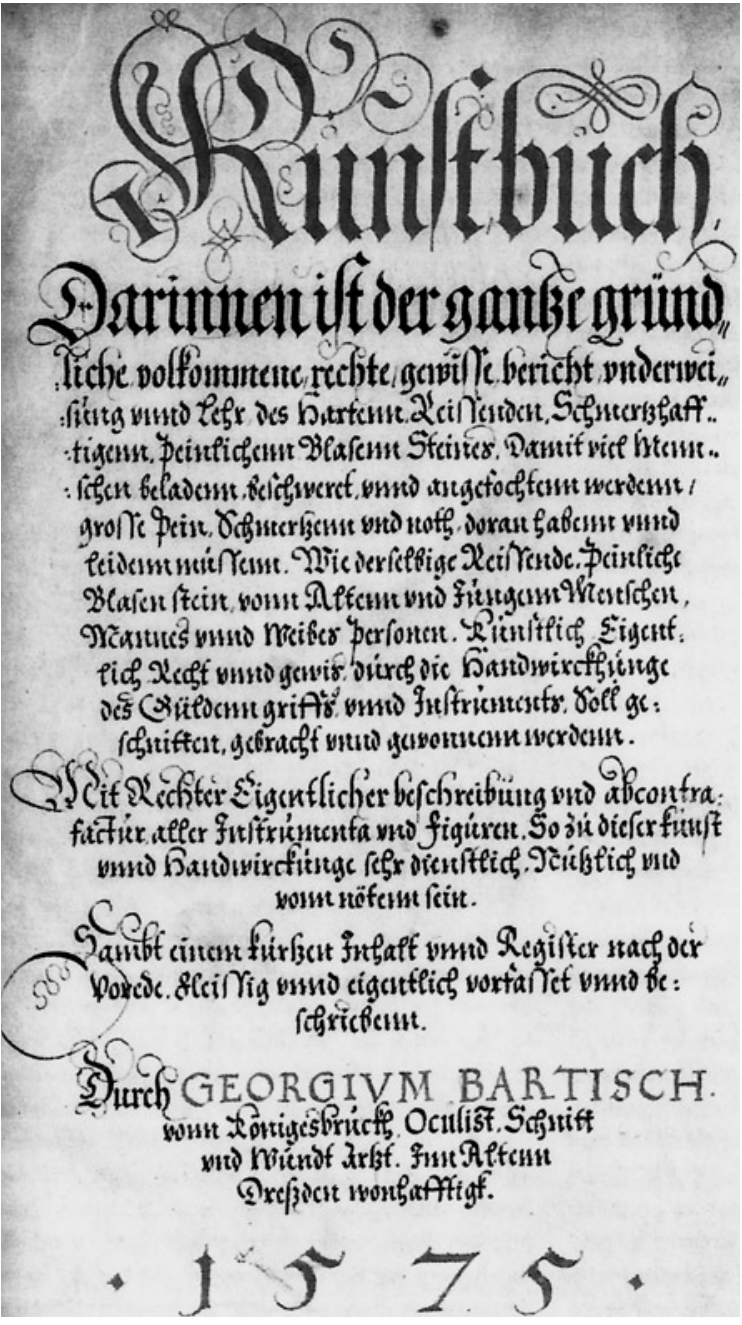

Fig. 5. Title page of Georg Bartisch's Manuscript about Lithotomy (1575)

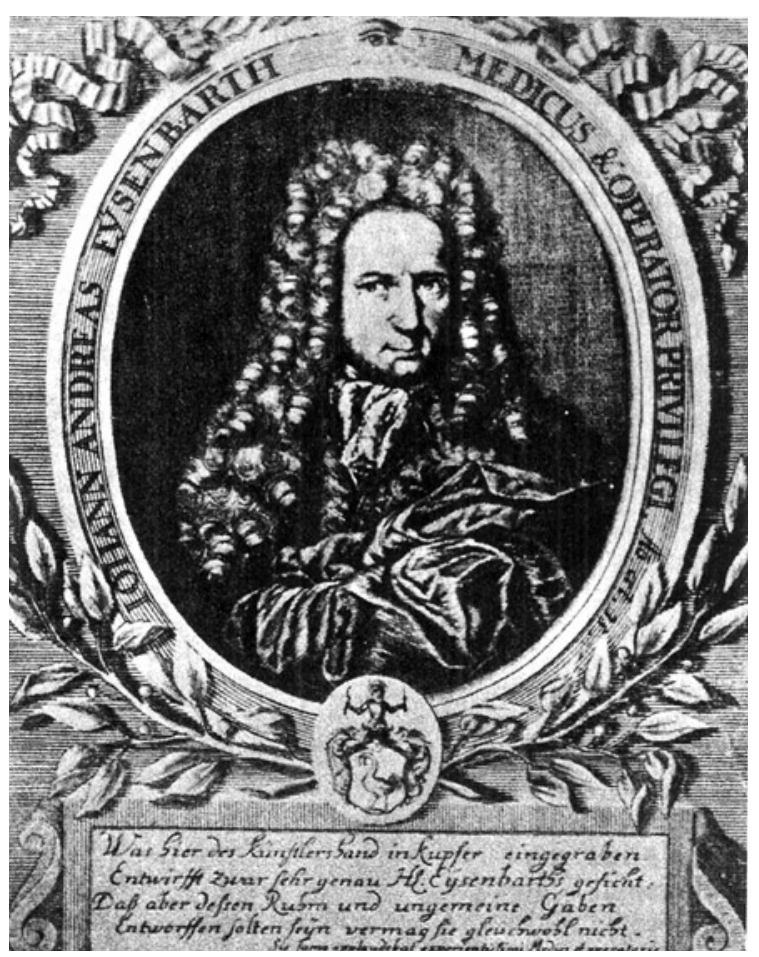

Fig. 6. Johann Andreas Eisenbarth (1663-1727)

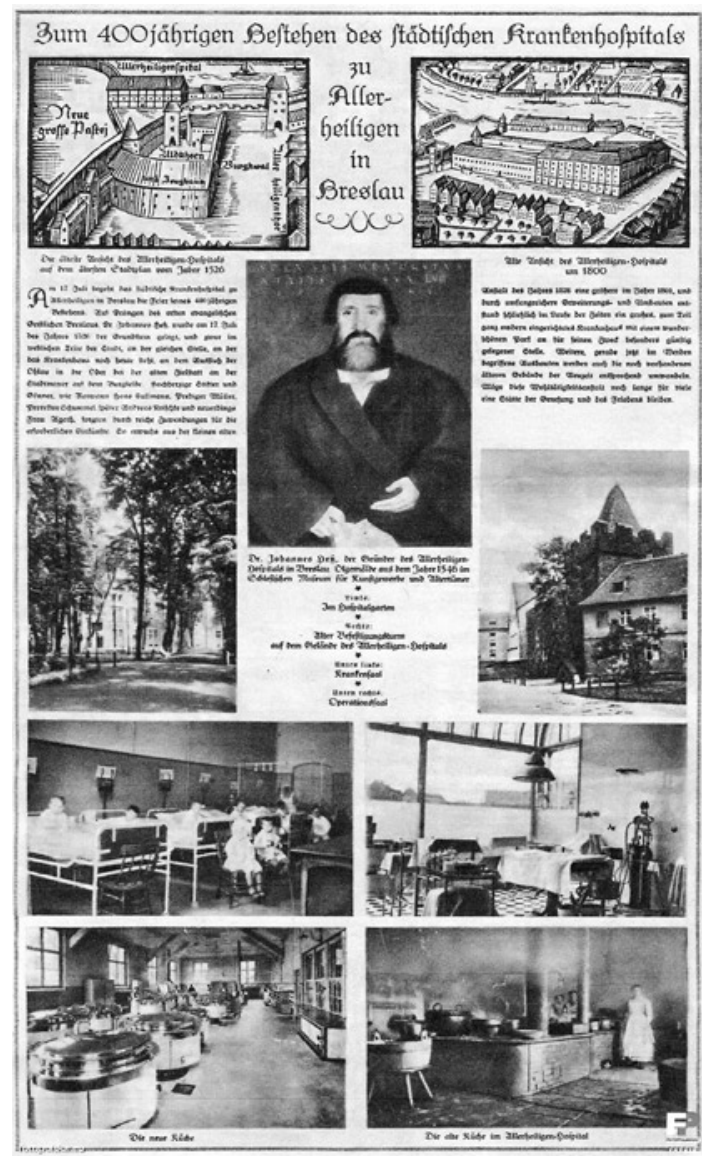

Fig. 7. The Founder of the first hospital, Johannes Hess (1490-1547)

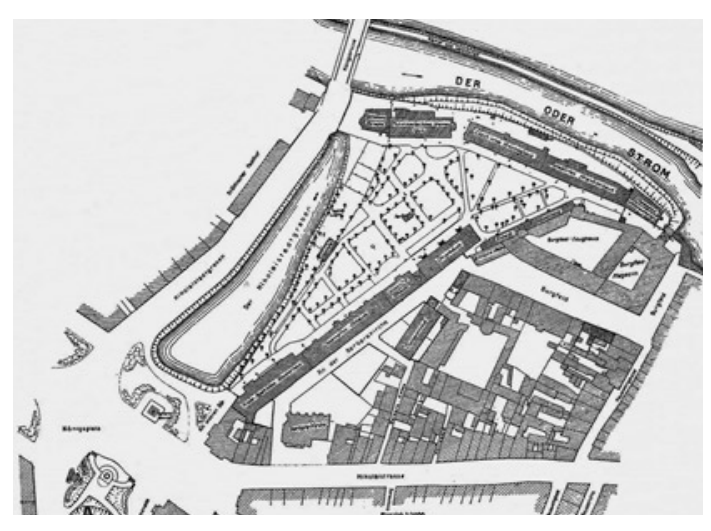

Fig. 8. The plan of the first hospital in Breslau (1912)

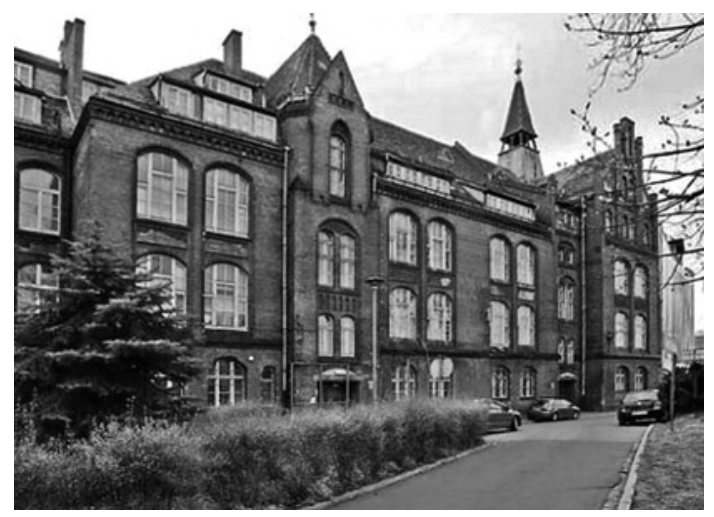

Fig. 9. All Saints Hospital today 
Elector, of being operating physician for Saxony, named himself "operating physician for the Kingdom of Poland" (Königlich Polnischen priviligierten Operator). A similar instance from the Duchy of Hanover bears out his acumen. Elector Georg Ludwig (1660-1727) named J.A. Eisenbarth physician for his Duchy. In 1714 Georg Ludwig became King of England, as George I. Eisenrath extended his privilege, calling himself "Physician to the Kingdom of Great Britain" (Königlich Groß-Britanischer Landarzt) [4, 10, 11].

\section{The first modern municipal hospital in Breslau - All Saints Hospital (Allerheiligen Hospital)}

Construction of the first buildings for a proper hospital in Breslau began in 1526. The founder of All Saints Hospital (Fig. 7) was Pastor Johannes Heß (Hesse, Hessus, 1490-1547). In subsequent years the hospital was expanded, and other hospitals also appeared in Breslau. Towards the end of the $19^{\text {th }}$ century the hospital had 1200 beds and was developing not just basic but also specialist activities (Fig. 8).

This large hospital complex, known as All Saints, existed for almost 500 years under a variety of names. When the hospital was taken over by the Polish administrative authorities in 1945, it was under the name All Saints. In 1949 the hospital was officially adopted by the state under the name State Provincial Hospital. In the years that followed its name was changed to the Józef Babiński Provincial Hospital, the Provincial Joint Hospital, and so on. From 1946 to 1953 the hospital was home to a urology department, among others, and then, up to 2007, to the Urology Clinic of the Academy of Medicine in Wrocław. In 2007 the Hospital was closed and no longer engages in medical activity (Fig. 9) $[3,4,12]$.

\section{University of Breslau}

In 1659 Emperor Leopold I (1640-1705) handed the Emperor's castle over to the Jesuits for them to set up a college there (later to become a university). Once they had gained the ownership title they gradually took down the

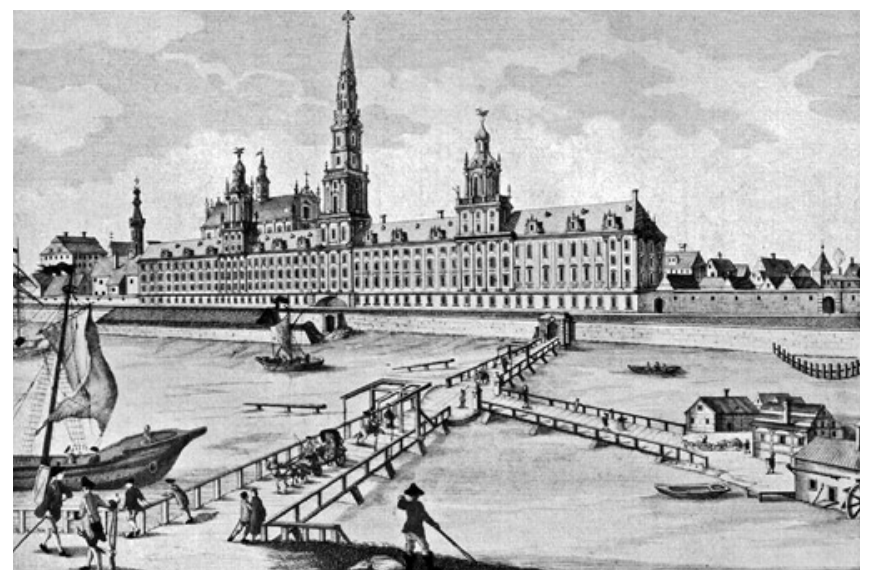

Fig. 10. The plan of the University of Breslau wings of the castle to build a new university block and a church dedicated to Jesus (Fig. 10).

In 1702 the Silesian ruler Leopold I Habsburg (1640-1705), Holy Roman Emperor of the German people and King of Bohemia, issued a foundation deed called "the Golden Bull" (Aurea bulla fundationis Universitas Leopoldine Wratislaviensis), on the basis of which the Jesuits' college was converted into a university; but owing to resistance on the part of the Protestant milieu in Wrocław and the authorities at the Jagiellonian University in Cracow, Leopoldina was left without a medical faculty. The first rector of the new educational institution in Breslau was the Jesuit Father Jakob Milbes (1648-1714).

A medical faculty was not opened until 1811, when Silesia belonged to the Kingdom of Prussia (Friedrich Wilhelm III, 1770-1840). There was, however, medical schooling in Wrocław between 1702 and 1811 (Fig. 11) [2, 4, 13].

\section{Medical schooling in Breslau}

The tradition of medical training at an intermediate level in Breslau goes back to the $18^{\text {th }}$ century. In 1745 the Prussian authorities set up a Collegium Medico-Chirurgicum in the building of the municipal All Saints Hospital (Allerheiligen Hospital), the purpose of which was to provide oversight of guild training for surgeons and midwives, and to verify their professional qualifications. In 1777 an Anatomical Centre was set up at All Saints Hospital in Breslau. In 1813, following amalgamation of Viadrina University in Frankfurt an der Oder with the Leopoldina in Breslau, the Institute of Anatomy received the name "School of Surgical Medicine", and this School co-existed with the university's medical department until 1849. Professors at the university were simultaneously lecturers at this School. In 1912, to mark the centenary of the amalgamation with Viadrina, the University of Breslau acquired the name of Friedrich Wilhelm (Fig. 12).

Until the first half of the $19^{\text {th }}$ century proficiency in surgery was gained by "surgeons" who were still being educated via the itinerant physician route, or by taking part in military actions in the role of surgeon's assistant (Feldscher = army

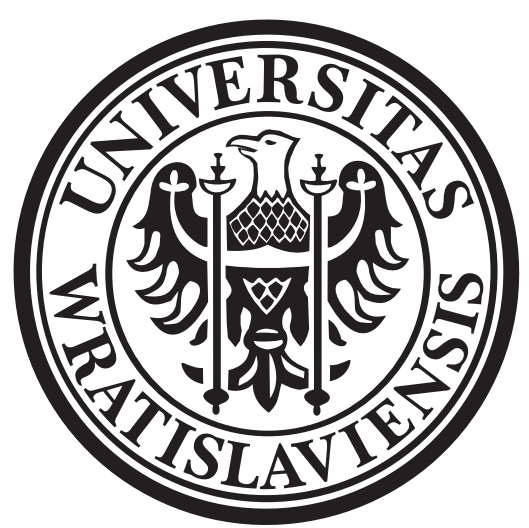

Fig. 11. Old emblem of the University of Breslau 


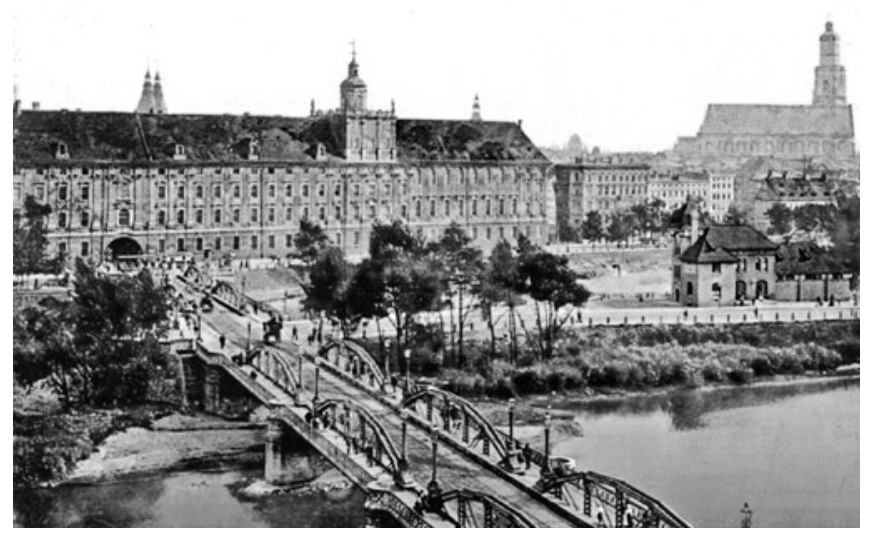

Fig. 12. The University of Breslau (1900)

surgeon). There were few who had any academic education. The period when a distinction was drawn between surgery and medicine came to an end in 1863, when the School of Surgical Medicine was closed down and surgery was incorporated into university education $[2,3,4,13]$.

\section{Faculty of Medicine of the University of Breslau (1811-1945)}

The introduction of surgery into lecture halls at medical departments as a subject of study, coupled with the appearance of university surgical clinics in the second half of the $18^{\text {th }}$ century, raised the importance and prestige of surgery. The University of Breslau's Faculty of Medicine had a department of surgery right from the start. The first full Professor of surgery in Breslau was Traugott Wilhelm Gustav Benedickt (1787-1862), appointed in 1812, who taught surgery and ophthalmology (Fig. 13).

Professor Johann von Mikulicz-Radecki (1855-1905) was the fourth director of the surgical clinic in Breslau (Fig. 14). He was primarily interested in urological diseases. He was the first head of department to set aside beds for urology patients at his Breslau Surgical Clinic, and to organise a separate urology outpatient department at the Clinic.

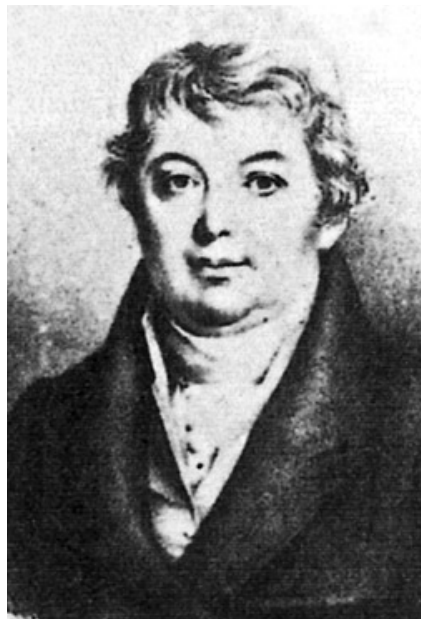

Fig. 13. Professor Traugott Gustav Benedickt (1787-1862)

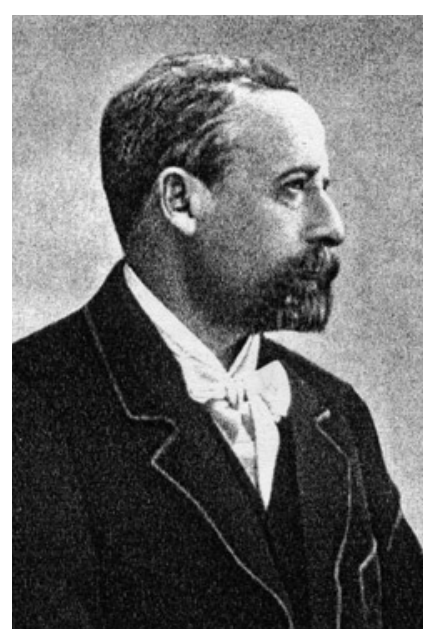

Fig. 14. Professor Johann von Mikulicz-Radecki (1850-1905)
Mikulicz was particularly involved in surgery of the genitourinary system. His operating spectrum took in almost the whole of surgical urology.

He performed ureterointestinal anastomosis in 1897 with Karl Maydl's technique, and the first ileocystoplasty, and published about it in 1898 . He operated on patients suffering from extrophy of the bladder and epispadia, floating kidney and patients with benign prostate hypertrophy, which were operated on in the perineal way. He performed surgery for urethral injury, stricture, tumours and fistulas. He enlarged the bladder with the aid of the small intestine, and operated on a urachal fistulae. He fixed wandering kidneys through transperitoneal access.

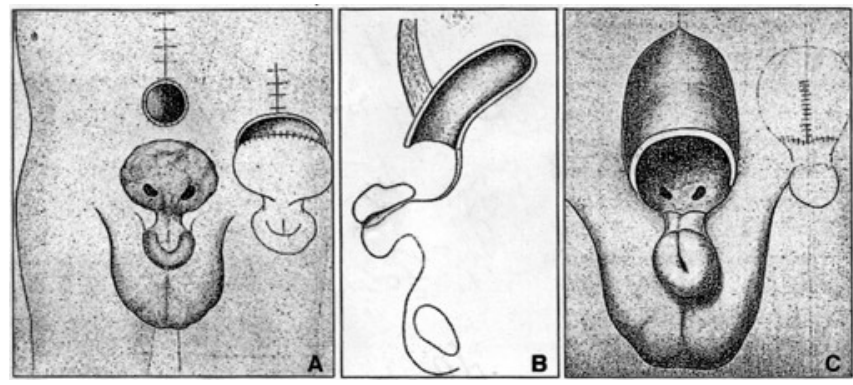

Fig. 15. Three steps of operation to bladder extrophy (1898)

In cases of bladder extrophy and a small bladder wall area, he proposed enlarging bladder capacity using a lower fragment of the isolated small intestine. In several further stages he reconstructed the urethra and carried out phalloplasty. In the last procedure he reconstructed the bladder neck and connected it to the urethra (Fig. 15). Mikulicz diagnosed radiological calculi in the lower part of the ureter, which he would surgically remove. Mikulicz also removed stones from the urinary bladder transurethrally (lithotripsy) or via a suprapubic section (Sectio alta, lithotomy) $[2,4,14,15]$.

\section{Rise of the Nazis and the problems of minorities. National Socialism}

The 1900 census listed 5,363 persons in Breslau (just over $1 \%$ of the population) declaring themselves to have competent knowledge in the Polish language only, and another $3,103(0.7 \%$ of the population) as competent in Polish as a second language. In the religious respect, $58 \%$ of the population were Protestants, 37\% Catholics (including at least $2 \%$ of Poles) and 5\% Jews (20,536 in the 1905 census).

After the World War I the Polish community starting having masses in Polish in the Churche of Saint Ann, and from 1921 in St. Martin's church. A Polish consulate was opened on the Main Square, and additionally a Polish School was formed by Helena Adamczewska. During the month of August 1920, at the time of the Polish Silesian Uprising in Upper Silesia, the Polish Consulate and School were demolished, whilst the Polish Library was burned down by a mob. The number of Poles as a percentage of the total population 
dropped to $0.5 \%$ after the reconstitution of Poland in 1918. The changes after World War I spread a nationalistic frenzy among people, who saw their city turn into a forward post of Germany.

The city became one of the largest support bases of the NSDAP (Nazi party) movement, and in the 1932 elections the Nazi party received $43.5 \%$ of the popular vote in Breslau, making it the third biggest victory in Weimar, Germany. After Hitler took over the German government in 1933 political enemies of the Nazis were persecuted, and their institutions closed or destroyed. In the city the Gestapo began actions against Polish and Jewish students, Communists, Social Democrats, and trade unionists, and arrests were even made for speaking Polish in public. In 1938 the police destroyed the Polish cultural centre.

Many of the city's 10,000 Jews, as well as many other enemies of the Third Reich, were forced to emigrate or sent to concentration camps. A network of concentration camps and forced labour camps (Arbeitslager) was established around Breslau to serve the city's growing industrial concerns. Tens of thousands were imprisoned there. The number of Jews remaining in Breslau decreased from 23,240 in 1925 to 10,659 in 1933. Later, the Jewish and Polish minorities ceased to exist.

The last big event organised by the Nazi Sports Body, called Deutsches Turn-und-Sportfest (Gym and Sports Festivities), took place in Breslau from $26^{\text {th }}$ to $31^{\text {st }}$ July 1938 . The Sportsfest was held in Breslau to commemorate the $125^{\text {th }}$ anniversary of the German Wars of Liberation against Napoleon's invasion. The coat of arms in Breslau was changed by the Nazis in 1938, as it contained the letter "W" and was considered by them to be "too Slavic" (Fig. 1). Additionally, 88 locations in the city received new German names as part of the campaign of Germanisation. Most of the Polish elites also left during the 1920s and 1930s, while Polish leaders who remained were sent to concentration camps. During the war 363 Czech and 293 Polish prisoners, as well as resistance members from Western Europe, were executed by guillotine in the city's prison.

In addition, a network of concentration camps and forced labour camps was established in the district around Breslau. The total number of prisoners held at such camps exceeded many tens of thousands. Official Nazi estimates reported 43,950 forced labourers in 1943 and 51,548 in 1944, most of them Poles. At the end of 1944 about 60,000 captured Poles were sent to Breslau after the crushing of the Warsaw Uprising.

On $12^{\text {th }}$ January 1945 Gauleiter (high District functionary of the Nazi party and administration) Karl August Hanke (1903-1945), on the orders of Adolf Hitler, declared the city a fortress (Festung), i.e. a stronghold to be held at all costs, and banned the city's inhabitants from leaving. The Hanke finally lifted a ban on the evacuation of women and children when it was almost too late. During his poorly organised evacuation in January and February 1945, around 18,000 people froze to death, mostly children and babies, in icy snowstorms and $-20^{\circ} \mathrm{C}$ temperatures. Some 200,000 civilians, less than a third of the pre-war population, remained in the city, because the railway connections to the west were damaged or overloaded.

Throughout most of the World War II Breslau was not close to the fighting. The city became a haven for refugees, swelling in population to nearly one million. In February 1945 the Soviet Red Army approached the city. Concentration camp prisoners were forced to help build new fortifications. In one area the workers were ordered to construct a military airfield intended for use in resupplying the fortress, while the entire residential district along the Kaiserstraße was razed. The authorities threatened to shoot anyone who refused to do their assigned labour. Eyewitnesses estimated that some 13,000 died under enemy fire on the airfield alone. In the end, one of the few planes that ever used it was that of the fleeing Gauleiter Hanke.

In February 1945 the Soviet Red Army approached the city after long and heavy fighting against the German defenders. They entered Breslau no earlier than (at least) $6^{\text {th }}$ May 1945. By the end of the Siege of Breslau over half the city had been destroyed. An estimated 170,000 civilians, including forced labourers, lay dead in the ruins of homes and factories. After a siege of nearly three months "Fortress Breslau" surrendered, on $7^{\text {th }}$ May 1945. It was one of the last major cities in Germany to fall. The military losses were 6,000 German soldiers and 7,000 Soviets [1, 13, 16, 17, 18, 19].

\section{University of Breslau, or Wroclaw since 1945}

As a consequence of the offensive on the Vistula launched by the Soviet Red Army in January 1945, all civilian institutions in the city were closed down, among them the university, with the aim of "total defence" of the besieged city.

On $22^{\text {nd }}$ January 1945 the university was transferred to Dresden. Most of Breslau's citizens, along with the teaching and administrative staff at the university, were forced by the Nazi authorities to leave the city. During the night of $13^{\text {th }}-14^{\text {th }}$ February 1945 the City of Dresden was destroyed in air raids of Allied forces. At the time of the bombing the city had 700,000 inhabitants and about 300,000 refugees.

Approximately 30,000 people were killed. Lost too were the University of Breslau's collections and also several of its staff. A prime example is Dr. Georg Kelling (1866-1945), the man who introduced modern laparoscopy into medicine. He, together with his second wife Johanna, died in an air raid of Allied forces on $14^{\text {th }}$ February 1945 in Dresden.

After the conclusion of the war Allied leaders met in Yalta and Potsdam, where they decided to return Poland to its medieval boundaries. The Polish frontiers shifted 120 miles west, and Breslau became part of Poland. The city's remaining German population of 189,500 fled westward during 1944-1945, or were evacuated or expelled in subsequent years. 
The end of World War II brought about a new political situation in Europe. Breslau, now Wrocław, and the entirety of Silesia became part of Poland. After 243 years of its existence the German university virtually ceased to exist.

A second historical epoch for the University of Breslau began, which, along with the Breslau Polytechnic Institute, on $24^{\text {th }}$ August 1945, by a decree of the Council of Ministers and the Presidium of the Polish National Council, became a Polish state academic school. In October 1945 the university resumed its teaching and research functions.

In 1945, after the end of the war, new Polish teaching staff began to move to Polish Wrocław, mainly from Lwów (now Lviv, Ukraine), Wilno (now Vilnius, Lithuania) and Grodno (now Hrodna, Belarus), all formerly Polish universities.

Almost all of the German populace were repatriated beyond the Oder to one of the two post-war German states (East and West Germany) between 1945 and 1949. Their place was largely taken by Polish people who had been driven out of eastern Polish lands beyond the River Bug. The population of Wrocław was soon enlarged by $75 \%$ due to the resettlement of Poles forming part of the post-war repatriation of Poles (1944-1946), as well as the forced deportations from Polish lands annexed by the Soviet Union in the east.

Between 1939 and 1941 about 2.5 million Poles from Eastern Poland were deported into the depths of the USSR.

Thousands of Poles, including some 25,000 officers, were murdered by the NKVD (People's Commissariat for Internal Affairs, Soviet Secret Police, head: Lavrenty Beria 1899-1953), and hundred thousands more were exiled to the depths of Russia.

There were 1145: Polish villages and settlements in Volhynia. Since 1943, after "anti-Polish campaign" (Massacre methodical exterminations of Poles living) by Ukrainian Insurgent Army (UPA), 1055 of them has been completely destroyed, survived were only 90 villages. The number of Poles murdered $1943-1945$ by Ukrainian nationalists can only be roughly estimated at 150-200 thousands, mostly of them were annihilated rural inhabitants. Polish Volhynia Life could not have been reborn.

The following description of the influence of the totalitarian ideologies on the development of science contains a warning that such an influence in medicine can mostly lead to criminal acts $[2,4,13,16,17,18,19,20,21]$.

\section{Beginning of separate and independent urology in Polish Wroclaw}

Until the end of 1945 there was no separate urology department in Breslau. Urological surgery was in the hands of surgeons. Interventions and operations on genitourinary organs were carried out, more or less, in all surgical departments. Over the centuries manual intervention was also in the hands of the non-academic persons such as bath house attendants, barbers, and wandering surgeons.
In Breslau and in the province outlying the city a large number of dermatologists and venereologists, surgeonurologist also treated urological patients. Many of them ran private urology practices, and operated at hospitals, sanatoria or private clinics, especially in the spa resort Bad Warmbrunn (today Cieplice Spa). A prime example is Dr. Felix Loewenhardt (1859-1911), the man who was a co-founder of the German Association of Urology (GAU) in 1906 and in 1907, during the first GAU Meeting he was elected the treasurer of its Committee (Board).

Felix Loewenhardt was born on $18^{\text {th }}$ June 1859 in Prenzlau. He graduated from the University of Halle-Wittenberg, where he obtained his medical degree with his postdoctoral thesis entitled Using of the elastic ligatures in abdominal surgery - their mechanism of action and fate ("Versuche über das Schicksal und die Wirkungsweise elastischer Ligaturen in der Bauchhöhle"), in 1884. He learned surgery under supervision of professors Richard Volkmann (1830-1889) and for many years in Clinic of Prof. Karl Hueter (1838-1882) in Greifswald. Thereafter he worked at Dermatological Clinic in Breslau. Later he ran private practice for dermatology and urology in Breslau.

Doctor Felix Loewenhard's scientific legacy runs to many published papers connected to kidney and bladder diseases and dermatology. He devoted himself to renal and urethral surgery and transurethral therapy of the bladder ailments for example tumours and stones. He was engaged with his favourite profession dermatology also. He died on $1^{\text {st }}$ December 1911 in Breslau.

The political changes in Europe after World War II accelerated the process of separating urology from surgery. The Wrocław Urology Centre owes its foundation mainly to the personality, considerable professional abilities and determination of Prof. F. Nowacki, and also to favour and strong support from superior authorities for Prof's Wiktor Bross (1903-1994), surgeon and Stanisław Laskownicki (1892-1978), urologist. In October 1945 Prof. F. Nowacki began work as an associate (adjunct) at the Surgical Clinic of the University of Wrocław (head: Prof. Wiktor Bross).

In February 1946 Prof. F. Nowacki set up a large urology and surgery department at All Saints Hospital, with 73 beds (Fig. 9). From 1948 his department concentrated exclusively on urology. Thanks to the initiative taken and the efforts invested by Prof. F. Nowacki, this department became the premier (first) urology department in Lower Silesia, and at the same time the largest department of urology in the country. The rare merits of its director, his vast surgical experience coupled with his superior talents in diagnosis and operating, and his great vocation for urology, which he had acquired in Dr. Wacław Lilpop's (1884-1949) Warsaw urological department, caused the department to rise rapidly to become one of Poland's major urology centres.

At this time, nurses, students and physicians were trained in urology at the department. In December 1951 Prof. F. Nowacki qualified as a university lecturer, with his postdoctoral thesis entitled Dynamics of the ureter under 
the influence of pharmacological stimuli and novocaine blocking in the light of endoscopic electro-urethrography. Two years later, on $1^{\text {st }}$ August 1953, the department was transformed into an independent 70-bed Urology Clinic of the Academy of Medicine in Wrocław. Professor F. Nowacki became its director, and a year later he was awarded the title Associate Professor. This was the third academic Urology Clinic to come into being in Poland.

The Academy of Medicine Urology Clinic in Wrocław was located at All Saints Hospital (the Józef Babiński Provincial Hospital in Wrocław) until 2006. The hard work and indomitable will of Prof. F. Nowacki ensured that the clinic was properly organised from top to bottom, raising it in a short time to the level of the most modern clinics - in research, in its teaching activities and in the services it provided. Despite major problems with staff and a meagre and inadequate array of equipment and medical apparatus, innumerable patients received treatment in the fast-developing city. A small team of doctors with modest experience (Except the Chief of Urology) had to cope with a large number of patients with urological diseases. The hard work and 12-hour shifts in the department soon eroded the health of some doctors, and particularly the clinic's director.

As the director of the clinic and an academic teacher, Prof. F. Nowacki succeeded in convincing the educational institution's authorities that lectures needed to be introduced for students of medicine, which were to be held on a regular basis for older (advanced) students. During Prof. F. Nowacki's illness, and after his death in 1957, the duties of head of department and director of the clinic were performed by Dr. Władysław Dobrzęcki (1914-1983), who was acting head of the Department of Urology. A few years later, in 1971, he was subsequently given the post of director of the urology department at the Railways Hospital [4, 22, 23, 24, 25, 26].

\section{Florian Nowacki (1902-1957) - the first Professor of urology in Wroclaw}

Florian Wojciech Nowacki (Fig. 16) was born on $4^{\text {th }}$ April 1902 in Gąsawa, in the Żnin district, and went to primary school there. He began his secondary education in Wągrowiec, and continued in Poznań (Posen), where he matriculated in 1922. That same year he commenced studies at the Faculty of Medicine at the University of Poznań, from which he graduated in 1928, obtaining a medical diploma and the title Doctor of Medical Sciences (doctor medicinae universae). From March 1929 he specialised in surgery under Prof. Kazimierz Nowakowski (1879-1952) at the surgery department of the Municipal Hospital in Poznań. Having completed his specialist studies in 1935, he proceeded to work in the same department as deputy head (second-in-command) until 1938.

During the German occupation of Poland he worked as a physician in Warsaw. From December 1939 until July
1940 he was an assistant at the Ujazdów Hospital. Then, from August 1940 to August 1944, he worked as a urology assistant at the department of urology at the St Lazarus Hospital (head: Dr. Wacław Lilpop, 18841949). During the Warsaw Uprising he organised and ran a field hospital, right up to capitulation. From October 1944 to August 1945 he was in a prisoner-of-war camp at Zeithain in Saxony, where he worked as a surgeon at the war prison

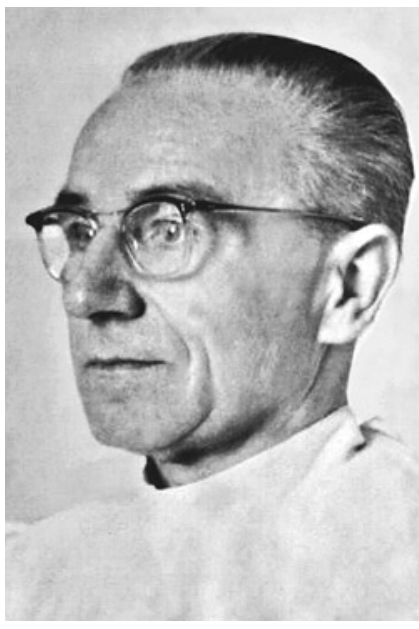

Fig. 16. Professor Florian Wojciech Nowacki (1902-1957) hospital. Following repatriation of the prison-camp hospital to Poland in September 1945, he made his way to the Regained Territories, and from $1^{\text {st }}$ October 1945 he began working as a urology surgeon at the No. II Surgery Clinic of the University and Polytechnic in Wrocław, the head of which was Prof. Wiktor Bross (1903-1994).

From 1946 Prof. F. Nowacki was at the same time the first head of the urological and surgery department at All Saints Hospital. In 1948 this department was transformed into the first independent urology department in Lower Silesia. In 1953 the department formed the basis for the establishment of the 70-bed Urology Clinic of the Academy of Medicine in Wrocław. During the years 1952-1957 Prof. F. Nowacki served as its first director. In 1955 Prof. F. Nowacki set up a sanatorium department in Cieplice (Bad Warmbrunn) for the treatment of urinary calculi, and a Research Centre.

In 1957 Prof. F. Nowacki suffered a heart attack. After a long period of illness and rehabilitation he diagnosed kidney cancer in himself. He underwent an operation in Warsaw and died on $19^{\text {th }}$ June 1957, several days after a nephrectomy, of an embolism of the pulmonary artery.

Professor F. Nowacki is remembered as a good physician, an excellent surgeon and a fiery patriot, who made a huge contribution to the development of urology in Lower Silesia [22, 25, 26, 27].

\section{Successors of Professor F. Nowacki}

Władysław Dobrzęcki (1914-1983), adjunct, independently ran the clinic during Prof. F. Nowacki's illness in the period 1955-1958. Professor Tadeusz Zygmunt Lorenz (1906-1986) ran the clinic from 1958-1976. From 1976-1988 the clinic's director was Doc. Jarowit Stolarczyk (1926-2011), and during 1988-2005, Prof. Jerzy Bogusław Lorenz Jr. (*1935) headed the clinic. When Prof. J. Lorenz retired in 2005, Prof. Romuald Zdrojowy (*1956-), born and raised in Wrocław, took over the directorship of the clinic and the Faculty of Urology at the Wrocław Academy of Medicine [23]. 
Władysław Dobrzęcki (Fig. 17) was born on $24^{\text {th }}$ February 1914 in Sokal, Galicia. He finished his secondary school and received his certificate in Żółkwia (today in Ukraine) in 1933. He studied medicine at the Polish Jan Kazimierz University in Lwów, and graduated (final exams) in 1939. In 1935, as a student, he began to work as a volunteer, at first at the Internal Clinic and later on at the Surgical Department (head: Prof. Adam Gruca, 1893-1983) until September 1939. Due to the outbreak World War II he left Poland for France, where he worked at military hospitals.

As a member of the Sanitary Corps he fought against Germany in 1940. In July 1940 he was taken into captivity by the Germans and imprisoned in an internment camp, "Lager", as a prisoner of war. In May 1942 he escaped and went, via France and Gibraltar, to Taymouth Castle in Great Britain, where he worked at the Surgical Department of War Hospital No I. Thereafter, in 1944, he was incorporated into the First Polish Armoured Division. As a surgeon he attended in all war activities on the Western Front and was twice wounded. After the war he became head of the Department of surgery at the $1^{\text {st }}$ Polish Forces Military General Hospital in England.

In October 1947 he returned to Poland. After collecting his professional documents he started his Surgical/urological curriculum under Prof. F. Nowacki in Wrocław, in March 1948. He became a urologist in 1951, and in 1960 obtained his medical degree from the Wrocław Academy of Medicine. From 1953 he was an associate of Prof. F. Nowacki, and from 1955-1958, during the illness of his chief, he ran the Department of Urology. From 1958-1967 he worked as an associate of Prof. T. Lorenz. From 1967 he headed the Urological Ward at the Municipal Hospital in Wrocław. After the founding of the urological Department of the Railway Company in Wrocław in 1970, Dr. W. Dobrzęcki became head of this unit. He headed the facility until his premature death on $9^{\text {th }}$ September 1983 in Wrocław.

He was very active as a university teacher and scientist. He authored 63 papers in both Polish and foreign publications.

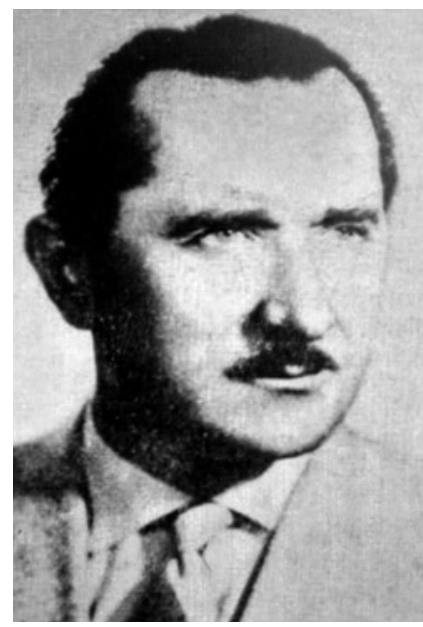

Fig. 17. Doctor Władysław Dobrzęcki (1914-1983)

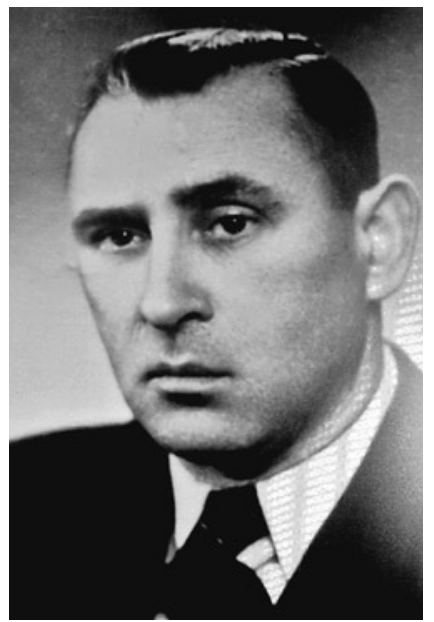

Fig. 18. Professor Tadeusz Zygmunt Lorenz (1906-1986)
Doctor W. Dobrzęcki presented papers at many scientific congresses in his native country and abroad. He took an active part in numerous symposia and conferences. For many years he was involved in the work of the Polish Urological Association (PTU). Under his guidance 10 doctors became urologists.

On $1^{\text {st }}$ February 1958, Prof. T. Lorenz (1906-1986), a disciple of Professor Laskownicki and head of the Urology Ward in Gdańsk (Danzig), was appointed director of the Urology Clinic and head of the Urology Department of the AMW [22, 28, 29].

Tadeusz Zygmunt Lorenz was born on $21^{\text {st }}$ January 1906 in Drohobycz. He graduated at the University of Lwów in 1933 (Fig. 18). His professional work began in Cracow and Lwów. He received his urological training in Lwów (1935-1938) in the Urological Department at the State General Hospital in Lwów (head: Professor Laskownicki). In November 1942 Dr. T. Lorenz became head of the Urology Department in Lemberg (Lwów), and he ran it until $20^{\text {th }}$ July 1944.

Then he escaped from Lwów to Poland. He worked as a urologist in Dąbrowa Tarnowska and Gdynia. From 1947 until 1958 he ran a 30-bed Urological Ward in Gdańsk. On $10^{\text {th }}$ October 1954 he qualified as a university lecturer with his postdoctoral thesis. In 1958 Doc. T. Lorenz left Gdańsk and took over the Urological Clinic with 70 beds at the Medical Academy in Wrocław (Breslau), after Prof. F. Nowacki.

In this post he succeeded in all the stages of a full academic career, in both science and the administration of the Academy. In 1959 he became Associate Professor, and in 1969 Full Professor. He was a very good organizer and operator. Professor T. Lorenz organized three Conferences of the PTU: 1955 - Gdańsk, 1960 - Wrocław, and 1963 - Jelenia Góra (Hirschberg). He authored or co-authored 61 papers in Polish and foreign publications. He was a co-founder of the PTU in 1949, and an Honorary Member of the Polish Urological Association. Professor T. Lorenz

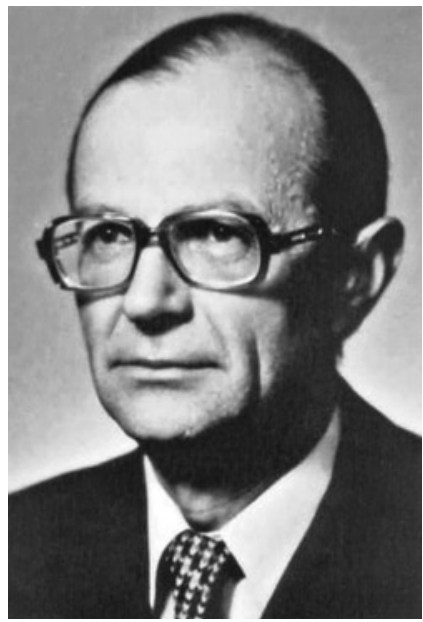

Fig. 19. Docent Jarowit Stolarczyk (1926-2011)

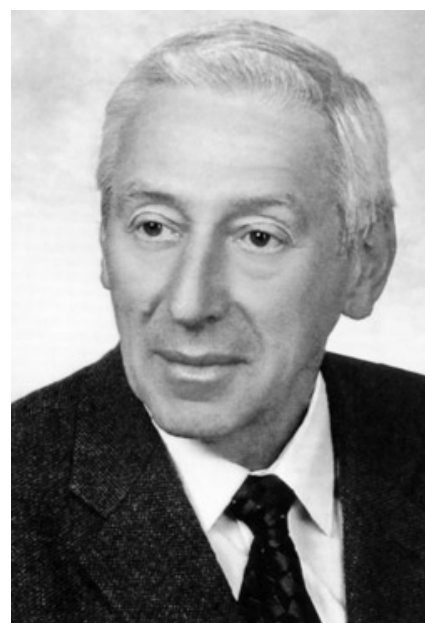

Fig. 20. Professor Jerzy Bogusław Lorenz $(* 1935)$ 
died on $3^{\text {rd }}$ January 1986 in Wrocław, following surgery for nephrolithiasis [22, 23, 24, 30, 31].

After the retirement of Prof. T. Lorenz in 1976 Doc. J. Stolarczyk (1926-2011) became head of the department.

Jarowit Stolarczyk was born on $15^{\text {th }}$ August 1926 in Białystok, as the son of a rural teacher. He finished primary school in Ciechanowiec. In 1938 he started his education at the Gimnazjum (High School) in Bielsk Podlaski. After the Soviet occupation of Poland in 1941 his family was deported to Ust-Kutam, Siberia. In the early days of World War II his father was killed. Jarowit attended school in Siberia, but after one year he broke off his education. He had to work as a woodcutter to feed the family. In 1943 he joined the Polish First Army in the USSR. It was the only possibility for the hundred thousand Poles to escape a life of slavery in the Soviet Union. As a soldier he fought against the Germans. He was demobilised in 1946. After the war he studied in High School and received his secondary school certificate in Wrocław in 1947. He graduated from the Medical Academy in Wrocław in 1952 (Fig. 19).

He began urological training under Prof. F. Nowacki and finished under Prof. T. Lorenz. Doctor J. Stolarczyk became a urologist in 1958, and obtained his medical degree in 1964. In 1974 he qualified as an Assistant Professor (Docent, lecturer) in urology at the Medical Academy in Wrocław, on the basis of his paper Vesico-ureteral reflux by children-a monograph.

In 1976 Doc. J. Stolarczyk took over the urological clinic with 70 beds at the Medical Academy in Wrocław after the retirement of Prof. T. Lorenz. The focus of his clinical activity was urooncology and paediatric urology. Jarowit Stolarczyk introduced and popularised the transperitoneal approach in surgical operations on kidney tumours in 1986. At that time the number of radical cystectomies in the treatment of invasive cancer of the bladder also increased. He led the Department of Urology until 1988. He authored over 90 publications and was co-author of the first Polish handbook "Urologia" (Ed. Professor Wesołowski). He was co-translator of the Czech handbook "Paediatric Urology" (Ed. Professor Bedrna). Docent J. Stolarczyk was awarded a number of prestigious Polish prizes. He died on $4^{\text {th }}$ September 2011 in Wrocław [2, 22, 23, 24].

After the retirement of Doc. J. Stolarczyk in 1988, Doc. J. Lorenz Jr. (*1935) became head of the clinical department of urology.

Jerzy Bogusław Lorenz was born on $27^{\text {th }}$ July 1935 in Lwów - at that time belonging to Poland (Fig. 20). His father was Prof. T. Lorenz, a urologist. Jerzy began primary school in Lwów and finished in Gdańsk. He attended the Lyceum (high School) in Gdańsk, where he attained his certificate in 1952. Thereafter, he enrolled at the Medical Academy in Gdańsk and graduated in 1958. Then he moved from Gdańsk to Wrocław, where his family already lived. Doctor J. Lorenz began his professional career in Wrocław. He became a general surgeon in 1963 and urologist (1966), and won his doctorate under the guidance of
Prof. Zdzisław Wiktor (1911-1970) and his father in 1966. In 1973 Dr. J. Lorenz qualified as a university lecturer with his postdoctoral Thesis entitled Local dissolution of urinary stones, and became a Professor in 1991. In his experimental work he tried, in vivo, to dissolve urinary stones. During the years 1985-1995 Prof. J. Lorenz served as chief of the Urological Department of the Provincial Hospital in Wrocław, and additionally from 1988 he ran, as Head, the Urological Clinic of the Medical Academy in Wrocław. He also supervised the Research Centre and a Sanatorium department in Cieplice (Bad Warmbrunn) for the treatment of urinary calculi and prostate ailments. In 2005, after spending 47 years of his life in Wrocław, Prof. J. Lorenz retired.

Since 1989 there have been profound socio-political changes in Eastern Europe which have laid the foundation for the rapid and revolutionary modernisation of medicine, and increased cooperation with western urologists. Under J. Lorenz's leadership, almost all contemporary diagnostic apparatus and therapeutic equipment and treatment methods of urological diseases were introduced for the improvement of the department. Among others, urine diversion to a substitute intestinal bladder was introduced in 1989. In 1990 the first radical prostatectomy was performed, and since then it has become the routine management for prostate cancer applied in the Clinic.

Professor J. Lorenz is the author or co-author of over 220 publications and conferences reports. In 1992 and 2002 he

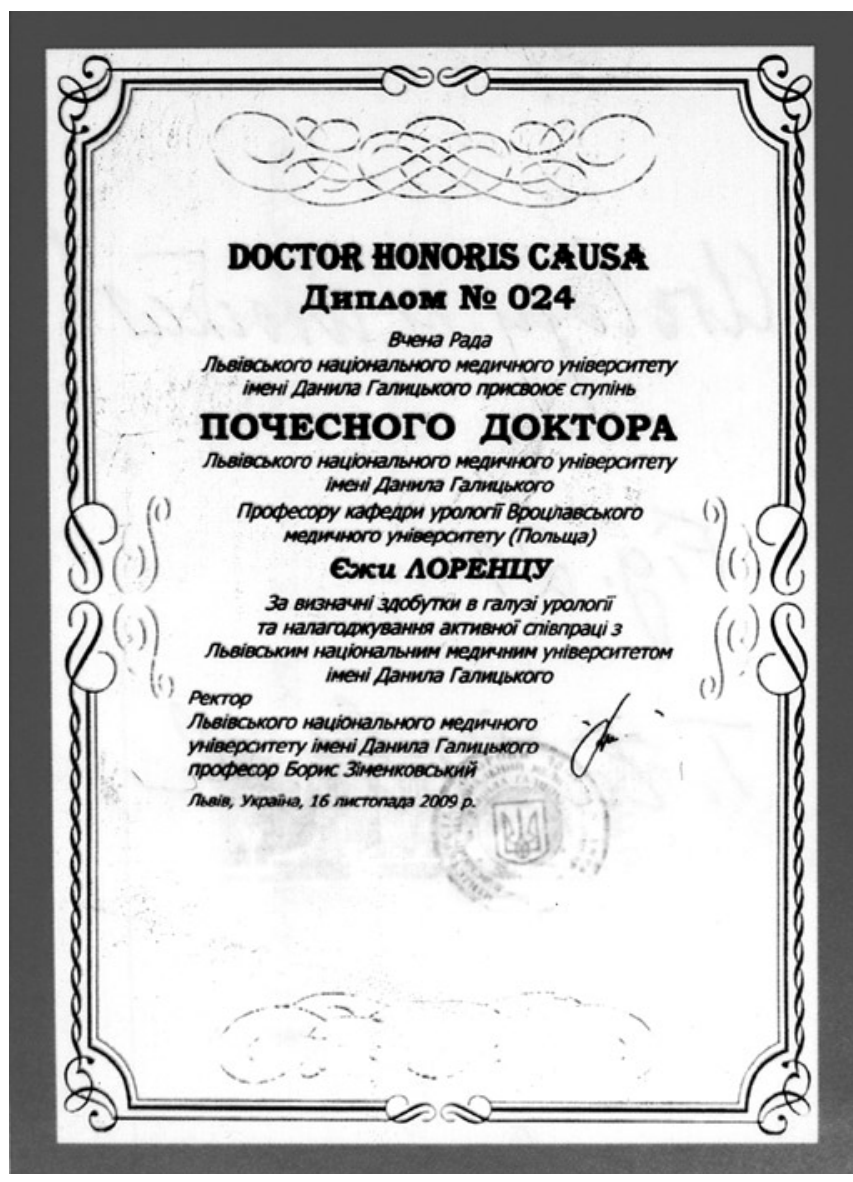

Fig. 21. Doctor Honoris Causa 
organised the Congresses of the PTU in Wrocław. From 1996 to 2004 he was editor-in-chief of "Urologia Polska” (,Polish Urology"). Professor J. Lorenz was awarded a number of prestigious Polish prizes and honorary membership of the PTU. For fruitful collaboration with the Department of Urology of the Medical University in Lviv Prof. J. Lorenz received the title "Doctor Honoris Causa" (Dr.h.c) from the Medical University of Lviv, Ukraine in 2009 (Fig. 21). Professor J. Lorenz and Prof. C.K. Borzhiewski, Head of the Department of Urology at the Medical University in Lviv, initiated and organized periodical Polish-Ukrainian Conferences. The conferences are continuing (Doctor Tereszkiewicz from Rzeszów, Dr. Anatol Majcher from Kędzierzyn-Koźle, Professor Zdrojowy from Wrocław, and Prof. Yurij Borys, with colleagues from Lviv). Altogether, from 2000 to 2011, five scientific symposia were held in Southern Poland and in Western Ukraine. The programmes of the conferences were always new and captivating [2, 3, 20, 21, 23, 24, 32, 33].

After Prof. J. Lorenz retired. in 2005, Ass. Prof. Romuald Zdrojowy $(* 1956)$ was appointed head of the Urological Department, and he continues to lead the facility.

Romuald Zdrojowy was born on $12^{\text {th }}$ June 1956 in Wrocław (Fig. 22). He attended the Classical High School in Wrocław, with the profile mathematics, where he attained a secondary school certificate with distinction in 1975. Thereafter, he enrolled in the Medical Academy in Wrocław, and graduated from the Academy of Medicine with an honourable mention ("red diploma") in 1981. After that he started his academic career in the urological Clinic of the Wrocław Academy of Medicine under the supervision of Doc. J. Stolarczyk, and from 1988 under the guidance Prof. J. Lorenz. During this period he became a general surgeon and urologist.

In 1987 he obtained his medical degree from Wrocław Adacemy of Medicine. In 2001 he qualified as a university lecturer, with his postdoctoral thesis entitled Therapeutic procedure in the case of local advanced prostate cancer, and in 2004 was nominated Professor. In 2005 Prof. Romuald

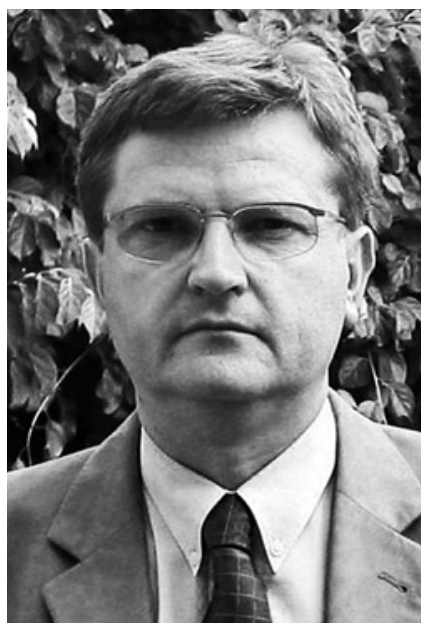

Fig. 22. Professor Romuald Zdrojowy $(* 1956)$

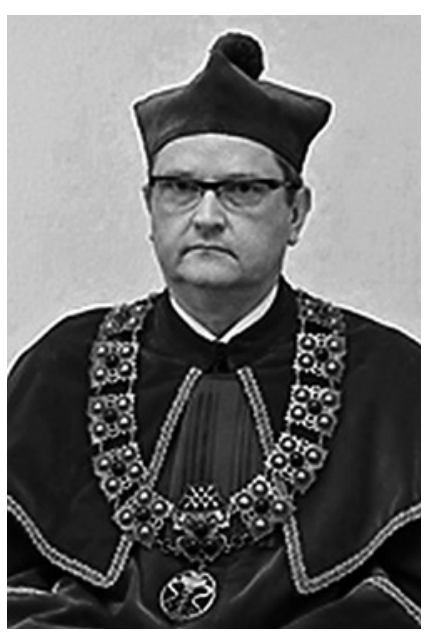

Fig. 23. Professor Romuald Zdrojowy, prorector (vice-chancellor)
Zdrojowy became Head of the Urological Clinic at the AMW. Since 2011 he has been the Pro-rector for Clinical Affairs at the University of Medicine in Wrocław [2, 4, 20, 21, 23, $24,31,33]$.

\section{Urology in Wroclaw today}

Professor Zdrojowy and his predecessor Prof. J. Lorenz organised and equipped the clinic to modern standards. Nowadays, the Clinic has pretty much all the equipment and diagnostic and therapeutic apparatus, including equipment for preventive procedures, needed to meet contemporary standards in the field of urology. Apart from its involvement in a wide range of surgical urology the clinic also employs every modern method of treating urinary calculi (ESWL, URS, PCN), and carries out endoscopic procedures and a wide spectrum of laparoscopic operations. The clinic possesses newly-equipped laboratories for urodynamic procedures, ultrasonography, and photo-diagnosis of bladder cancer, as well as laser therapy. Recently, the majority of the scientific projects have been devoted to the role of neoplastic markers in the diagnosis and monitoring of uro-oncology.

From 2009-2012 Prof. Romuald Zdrojowy was editor-in-chief of the "Central European Urological Journal of Urology". He is the author or co-author of over 350 scientific publications and numerous book chapters. For some years he has been involved in the work of the PTU. He is a member of the Pathophysiology Commission of the Polish Academy of Sciences. He plays an active role on administrative committees of the University of Medicine in Wrocław, and is currently its vice-chancellor (Fig. 23).

During its existence the Department of Urology of the Medical Academy in Wrocław was located in the J. Babiński Provincial Hospital (All Saints' Hospital), but in 2007 it was relocated from All Saints' Hospital to the Silesian Piasts Clinical Centre of the Medical University in Wrocław, and is based at the Jan Mikulicz-Radecki Academic Clinical Hospital on Borowska Street. Today the clinic has 40 urological beds (Fig. 24) [2, 4, 23, 24, 31, 32].

Presently, in addition to the Urology and Uro-oncology University Clinic with 40 beds, there are three more independent urological units in Wrocław.

The Department of Urology in the Provincial Specialist Hospital (29 beds, 9 doctors) has been headed by Dr. Jerzy Sokołowski since 1996. The Department was opened in 1946. Professor F. Nowacki became the first head of this unit. Later on the unit was led by heads of the department of urology of the Medical Academy. In 1996 Prof. J. Lorenz resigned from his second post as head of the department.

The Railway Hospital, Department of Urology was founded in 1970. The first head of this unit was Dr. W. Dobrzęcki, followed by Dr. Edward Pinkas, from 1986 to 2003. Since 2004 Dr. Zenona Jabłońska has headed the urological department, with 25 beds, and 3 doctors and 2 residents. 


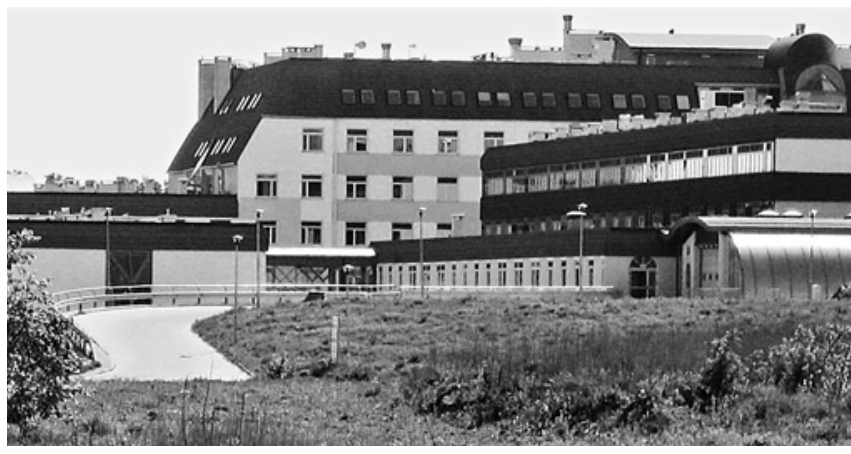

Fig. 24. Clinical Centre of the Medical University in Wrocław

The Department of Clinical Urology in the $4^{\text {th }}$ Military Clinical Hospital (29 beds, 11 doctors and 2 Residents). Docent Tomasz Szydełko has headed the department since 2011.

In 2012, altogether there were 119 urological beds in different hospitals in Wrocław. Today the University of Breslau is the biggest University in the region, with over 40,000 students and 10 faculties. About 9,000 students graduate every year. Statistical data from 2012 show Wrocław to have 630,000 inhabitants $[1,13,20,21,31,33]$.

\section{Epilogue}

In the history of Europe there are cities like Strasbourg, Prague, Danzig, Stettin, or university cities more closely associated with Poland, such as Grodno, Lviv or Vilnius. The list of these special cities also include Breslau, which belonged initially to Poland, then to Bohemia, for a short time to Hungary, later to Austro-Hungary, for the next 200 years to Prussia and Germany, and from 1945 it regained its Polish status.

The city of Breslau is a prime example of the influence that politics can have on its inhabitants and science. Changes in national status were often marked with tragedy for the country's inhabitants, who were relocated from their homeland where they were born and grew up. But this great wrong was often righted by the work and achievements of outstanding physicians, who were offered the highest academic positions and have found a permanent place in the history of medicine.

In 1949, the Faculty of Medicine was hived from the University and turned into separate educational institution - the Medical Academy of Wrocław, which is now a multi - departmental entity and is known as a Medical University of Wrocław.

The University of Wrocław (Polish: Uniwersytet Wrocławski; German: Universität Breslau; Latin: Universitas Wratislaviensis) is one of nine universities in Wrocław, Poland. Formerly, the German university was founded in 1702 as Leopoldina, and re-founded in 1811 with a medical faculty as Schlesische Friedrich-Wilhelms-Universität zu Breslau. The history of the contemporary Polish university started in 1945, after the area passed to Poland. The university was established primarily by academics from the former University of

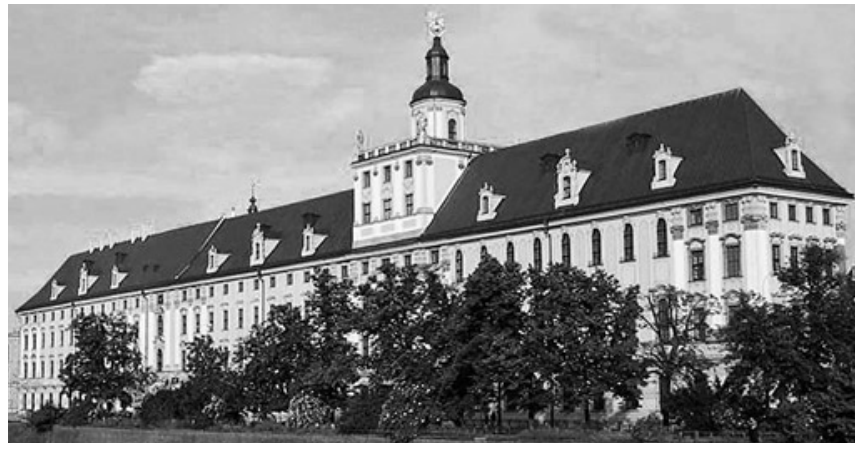

Fig. 25. University of Wrocław today

Lwów. Today the University of Wrocław is the largest university in the region, and teaches over 43,000 (2012) students and around 1,300 doctoral students in 10 faculties. 9,000 students graduate from the University every year (Fig. 25).

\section{References}

1. Brief history of Wrocław. http://www.wroclaw.co/history ( $17^{\text {th }}$ June 2013)

2. Kozuschek $W$ : Geschichte der Medizinischen und Pharmazeutischen Fakultäten der Universität Breslau sowie der Medizinischen Akademie Wrocław in den Jahren 1702-2002. Wyd. Uniw. Wroc., Wrocław 2002.

3. Kozuschek W.: Selected disciplines and the contribution of Wrocław's medicine to the development of medical sciences in historical aspects. Akad. Med. we Wrocławiu, Wrocław 2000.

4. Zajaczkowski T: : Medical training and beginning of the urology in Breslau (Wrocław). Urol Rev. 2011, 12, 6, 74-79.

5. Lisowski W.: Doctors in the service of Polish Kings and Queens. "Scalpel". Military Medical Chamber in Warsaw. 2006, 2-3.

6. Lisowski W.: Thomas von Breslau - Ein Arzt schlesischen Fürsten. Skalpel. 2006, 3.

7. Jan Stanko. http://pl.wikipedia.org/wiki/Jan_Stanko (17 th June 2013).

8. John of Głogów. http://en.wikipedia.org/wiki/John_of_Głogów (17 th June 2013).

9. Nikolaus Kopernikus. http://de.wikipedia.org/wiki/Nikolaus_Kopernikus (17 ${ }^{\text {th }}$ June 2013).

10. Dietrich H.G., Hausmann H., Konert J.: Georg Bartisch (1535-1606) - Kurfürstich sachsischer Schnitt- und Wundarzt in der Zeit der Renaissance. In: Die Geschichte der Urologie in Dresden. Eds: Schultheiss \& Moll Springer, Heidelberg 2009.

11. Pies E.: Ich bin der Doktor Eisenbarth. Sprockhövel, J.F. Lemanns. Med Buchhandlung. Berlin Gießen Halle, Hamburg 1995.

12. Wojewódzki Szpital im. Józefa Babińskiego we Wrocławiu. http:// pl.wikipedia.org/wiki/Wojewódzki_Szpital_im._Józefa_Babińskiego_we_Wrocławiu (17 $7^{\text {th }}$ June 2013).

13. University of Wrocław, http://en.wikipedia.org/wiki/University_of_Wrocław (17 ${ }^{\text {th }}$ June 2013).

14. Zajaczkowski T: Johannes Anton Freiherr von Mikulicz-Radecki (1850-1905). Sein Beitrag zur Urologieentwicklung. Urologe. 2010, 49, 280-285.

15. Zajączkowski T.: Johann Anton von Mikulicz-Radecki (1850-1905)a pioneer of gastroscopy and modern surgery: his credit to urology". World J Urol. 2008, 26, 75-86.

16. Breslau. Weimarer Republik, Nationalsozialismus und Zweiter Weltkrieg. http://de.wikipedia.org/wiki/Breslau (17 $7^{\text {th }}$ June 2013).

17. Bombing of Dresden in World War II. http://en.wikipedia.org/wiki/ Bombing_of_Dresden_in_World_War_II (17 $7^{\text {th }}$ June 2013).

18. Hatzinger M., Badawi J.K.: Georg Kelling (1866-1945). The man who introduced modern laparoscopy into medicine. Hist Urol Europ. 2005, $12,163-170$. 
19. Cygan W.K., Skalski J.: Poland-in the defence of freedom 1939-1945. Barwa i Broń, Warszawa 2005.

20. Zajaczkowski T:: Education in medicine and surgery in Breslau - Development of urology in Breslau/Wrocław. Hist Urol Europ. 2014, 21, 138-173.

21. The New Encyclopaedia Britannica, $15^{\text {th }}$ Edition, vol. 25 and 28. Encyclopaedia Britannica Inc., Chicago, London, New York, Paris, Seoul, Sydney, Taipei, Tokyo 2003.

22. Archiv of Medical Academy in Wrocław. Hand written and printed biographies and documents. 2011-2012.

23. Zdrojowy R.: Katedra i Klinika Urologii i Onkologii Urologicznej. In: Chirurgia dolnośląska i opolska 1945-2009. Eds: W. Witkiewicz, B. Łazarkiewicz, W. Kozuschek. Wyd. Uniw. Wroc., Wrocław 2009, $147-153$.

24. Lorenz J., Kaczmarek A.: History of urology in Lower Silesia. In: 50-years of the Polish Urological Association. Ed. A. Borkowski. Vol. I-II. Remedy, Warszawa 2003, 489-502.
25. Dobrzęcki W.: Prof. Dr. Florian Nowacki. Urol Pol. 1958, 12, 1-2, $5-11$.

26. Stolarczyk J.: Prof. Dr. wszechnauk lekarskich Florian Nowacki (1902-1957). Urol Pol. 1992, 45, 53-54.

27. Borkowski A.: 50-years of the Polish Urological Association. Vol. I-II. Remedy, Warszawa 2003.

28. Pinkas E.: Dr. med. Władysław Dobrzęcki (1914-1983). Urol Pol. 1984, 37, 3, 238-241.

29. Zajączkowski T:: Dr. med. Władysław Dobrzęcki (1914-1983) - urologist and patriot. Prz Urol. 2012, 3, 73, 67-70.

30. Stolarczyk J.: Prof. Dr. med. Tadeusz Lorenz (1906-1986). Urol Pol. 1992, 45, 1, 54-56.

31. Zdrojowy R.: Personal reports (2012).

32. Skarbek M.: Medyczne przygody profesora Lorenza (Interview). Prz Urol. 2010, 11, 3, 23-28.

33. Władze Uczelni: Prorektor ds. Klinicznych. Prof. dr hab. Romuald Zdrojowy (życiorys). www.am.wroc.pl (17 $7^{\text {th }}$ June 2013). 